\title{
A native ground-nesting bee (Nomia melanderi) sustainably managed to pollinate alfalfa across an intensively agricultural landscape*
}

\author{
James H. CANE \\ USDA, Bee Biology and Systematics Lab, Utah State University, Logan, Utah 84322-5310, USA
}

Received 20 June 2007 - Revised 21 December 2007 - Accepted 14 Januay 2008

\begin{abstract}
The world's only intensively managed ground-nesting bee, the alkali bee (Nomia melanderi Cockerell), has been used for $>50$ years as an effective pollinator of alfalfa (Medicago sativa $\mathrm{L}$.) grown for seed in the western USA. Across a $240 \mathrm{~km}^{2}$ watershed in Washington, the 24 most populous of 56 nest sites found were annually surveyed for nesting bees for 8 years. Alkali bees multiplied 9-fold to 17 million females, the largest reported metapopulation of non-social bees. Several sites have remained populous for an unprecedented 50 years. The most populous nesting bed ( $1.5 \mathrm{ha})$ grew to 5.3 million nesting females (median $=278$ nests $/ \mathrm{m}^{2}$ ), the largest bee nesting aggregation ever recorded. This first-ever exhaustive landscape-level survey for any non-social bee reveals that even amid intensive conventional agriculture, a native bee can sustainably multiply to vast numbers, its nesting aggregations persisting for decades.
\end{abstract}

Apiformes / crop / Halictidae / Medicago / pollinator

\section{INTRODUCTION}

The primary challenge for agricultural pollination is to provide sufficient numbers of bees to match the vast blooms put forth by extensive crop monocultures. Exemplars for the magnitude of flower production per hectare include almonds (2 million) (Bosch, 1994), cranberries (6-50 million) (Farrar and Bain, 1946; Eck, 1986), and most dramatically, alfalfa (120-500 million) (Lesins, 1950; Pedersen and Nye, 1962). For these and many other crops, most flowers must be visited at least once by a bee for commercial yields of fruit or seed. For most zoophilous crops, the honeybee (Apis mellifera L.) remains the dominant pollinator (reviewed in Free, 1993). Honeybees prevail partly because of their foraging versatility, but mostly because each colony, housed in a mobile hive, can cheaply and reliably field

Corresponding author: J.H. Cane,

Jim.Cane@ars.usda.gov

* Manuscript editor: Jacqueline Pierre tens of thousands of pollinating foragers on demand. But why are honeybees needed at all?

Many crops are more effectively pollinated by one or more species of nonApis bees (Parker et al., 1987; reviewed in Klein et al., 2007), including diverse groundnesting species (Cane, 1997). Ground-nesters often dominate regional wild bee faunas; for instance, $85 \%$ of eastern North America's bee species nest underground (Cane, 2003b). However, for reasons of crop rotation and because nest sites cannot be readily prepared and colonized, ground-nesting bees are not generally managed to pollinate crops. A prominent exception is the alkali bee, Nomia melanderi Cockerell, a native to the arid desert basins of western North America. The bee is a floral generalist, but is valued as the most effective alfalfa pollinator (Cane, 2002). It nests gregariously in moist basin soils bearing salty surfaces (Johansen et al., 1978). Small $1-\mathrm{ft}^{3}$ soil cubes cut or cored from dense nesting aggregations are used to populate newly 


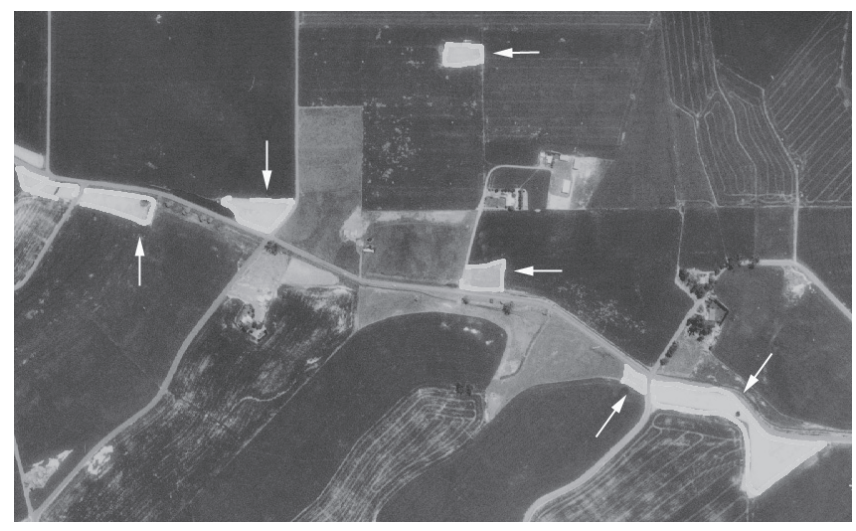

Figure 1. Aerial photograph of a 3-km wide portion of the Touchet Valley, showing growing alfalfa seed fields (dark) and alkali bee nesting beds (pale polygons indicated with white arrows). The lack of hedgerows, fallow fields or uncultivated land illustrates the valley's agricultural intensity.

prepared nesting sites amid alfalfa seed fields (Stephen, 1960). In most western U.S. growing areas, however, its use has been supplanted by managed populations of an adventive Eurasian cavity-nesting bee, the alfalfa leafcutting bee, Megachile rotundata Fabricius (Megachilidae). Managed populations of M. rotundata regularly dwindle on U.S. alfalfa seed farms, however, so growers annually replenish their stocks with billions of nest cells bought from Canadian producers (Pitts-Singer, 2004). It is impractical to frequently replenish $N$. melanderi stocks, so to benefit from this effective pollinator, growers must manage its populations sustainably.

Over the past half-century, alfalfa seed farmers have had variable success managing alkali bees. Suitable sites for alkali bee nest beds possess silty soils with good hydraulic conductivity, moist subsoils, and a surface free of vegetation that is periodically sealed with salt (typically $\mathrm{NaCl}$ ) (Johansen et al., 1978). Larval predators can be problematic, particularly bombyliid flies (Bohart et al., 1960) and oil beetles (Mayer and Johansen, 1978). Like other bees, alkali bees are susceptible to sundry insecticides (Johansen and Mayer, 1990) which if misapplied or mistimed can decimate their populations (e.g. Wichelns et al., 1992). Otherwise, factors driving population dynamics of this and other ground-nesting bees are rarely documented.
No species of solitary (non-social) bee has been exhaustively surveyed at the landscape scale, owing to the simple challenge posed by finding every nest. Spatially or temporally extensive surveys of bees report counts of individuals caught at flowers or passively trapped (reviewed in Williams et al., 2001). Neither measure allows calculation of the total numbers of bees residing in an area. The goal of this 8-year study was to survey and document population trends for the entire metapopulation of alkali bees nesting across an arid, irrigated $240 \mathrm{~km}^{2}$ agricultural landscape in Washington state USA.

\section{MATERIALS AND METHODS}

\subsection{Nesting aggregations}

Past and present nesting beds of alkali bees were surveyed and measured in the Touchet Valley west of Walla Walla, Washington, an alfalfa seed growing region since about 1950. Nesting beds there are subirrigated naturally, or subsurface water is distributed using moats or buried perforated pipes. The 56 currently or recently populated nesting beds were found through grower accounts and aerial photographs (National Resource Conservation Service). The white salt surfaces of nesting beds contrasts with the dark foliage of adjacent alfalfa (Fig. 1). Ages of some older nesting beds were known by growers, or obtained from old field research records. The surface area of each nesting 


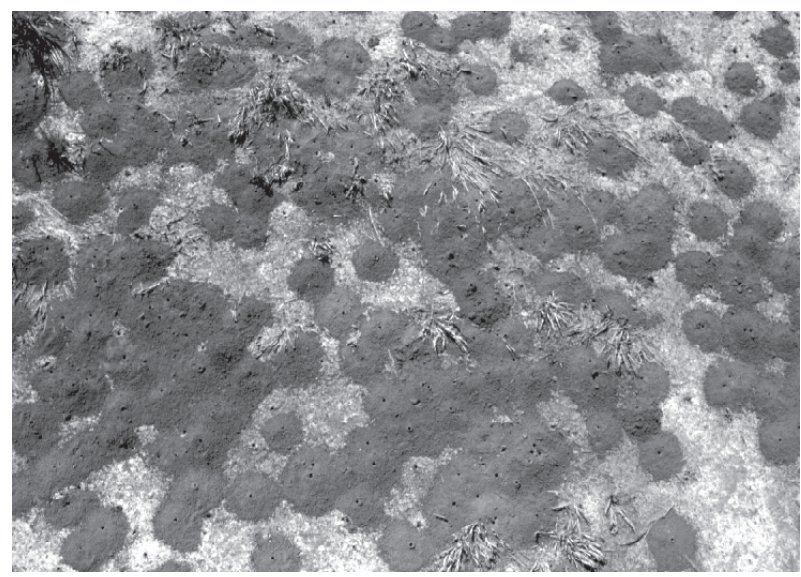

Figure 2. Surface of nesting bed showing new nests with soil heaps (tumuli) as well as emergence holes that are often reused for nesting.

bed was measured by planimeter on the aerial photographs, and confirmed or validated on the ground, especially those nesting beds that were expanded or renovated by growers during this study.

\subsection{Population measurement}

Nesting densities were annually surveyed in late June during peak alfalfa bloom after nests had been initiated. A female typically makes one nest (Bohart and Cross, 1955). Depending on aggregation size, 10 to 20 quadrats (each $1-\mathrm{m}^{2}$ ) were placed at random coordinates on every aggregation's surface. All holes within each quadrat were counted, both those with excavated soil heaps (tumuli) as well as emergence holes (Fig. 2), as pollen-laden females were commonly seen returning to emergence holes (Cane, 2003a). Reliability of the randomized quadrat method was checked by the same two persons counting nesting holes for three replicated sets of ten quadrats each on one small nesting bed. These were compared using a two-way ANOVA of survey-taker by quadrat set. No other groundnesting bee or wasp nested abundantly amid active Nomia aggregations. Average hole density per aggregation was multiplied by the measured area of the nesting aggregation to estimate the sum of holes per nesting bed. Counts of holes were converted to nest counts using observed frequencies of occupation (see below). The average annual rate of nest density change was estimated as the slope of a linear regression fitted to the valley's annual grand average of nesting densities.

\subsection{Nest hole utilization}

Videography was used in 2003 to verify the proportions of counted holes in actual use by nesting female alkali bees. On mornings of good nesting activity, a video camera was set to vertically view a marked $0.25 \mathrm{~m}^{2}$ rectangle of aggregation surface bearing discernable holes that were then counted. The view was filmed for $90 \mathrm{~min}$ and later replayed, counting every hole that a resident bee either departed or entered. Dubious brief entries were rare and not counted. In all, five aggregations were thus filmed, for a grand average of the fraction of holes in use. Each aggregation's annual total count of holes was multiplied by this average fraction of holes in use to estimate the total numbers of alkali bee nests per each aggregation.

\section{RESULTS}

\subsection{Nest hole utilization}

Many holes without tumuli were nonetheless active Nomia nests. The average morning foraging trip lasted $52 \pm 20 \mathrm{~min}(n=92)$, so filming for 90 min should have revealed nest occupancy. Of the 139 holes (23-31 per nest site) observed, 92 were in use $(66 \%$ overall, $55-83 \%$ per aggregation). Therefore, all hole counts in quadrats were multiplied by $2 / 3$ to arrive at an estimate of active nests per each aggregation. 


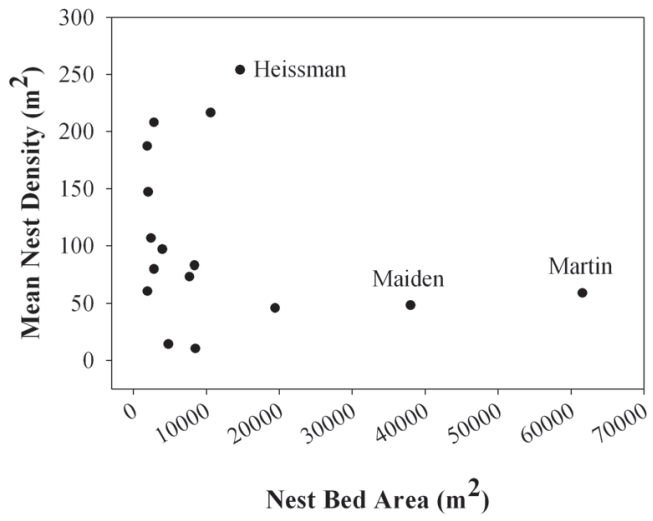

Figure 3. Relationship between nesting density and nest bed size for alkali bees in the Touchet Valley in 2006.

\subsection{Population variability}

Measured nesting densities varied widely within and between individual nesting aggregations. This variation was not an artifact; repeated surveys of the same nesting bed yielded nest density estimates that were within $20 \%$ of each other and statistically equivalent $(P>0.9)$. Active nesting beds ranged more than 100-fold in surface area, from 405 to $61600 \mathrm{~m}^{2}$. Valley-wide, 20 ha was dedicated to active alkali bee nesting beds, or about $0.6 \%$ of the area planted to seed alfalfa. Even at the populous Heismann bed, average density in the quadrats (256 nests per $\mathrm{m}^{2}$ ) was less than the greatest nest density measured there (713 nests per $\mathrm{m}^{2}$ ). If all nest beds were so populous, the valley's extant aggregations would have 60 million nests. All nest beds were therefore big enough to accommodate more population growth (Fig. 3).

\subsection{Aggregation and metapopulation growth}

Alkali bee populations multiplied dramatically between 1999 and 2006. Over eight years, valley-wide populations grew 9-fold to 16.7 million females (Fig. 4). Growers' expanded and improved two large and ultimately populous nesting beds (Martin and Maiden) (Fig. 5 No. 47 and No. 48; Fig. 3) adding 8 ha. of suitable nesting habitat; the large Heismann bed was not expanded. In general, populations

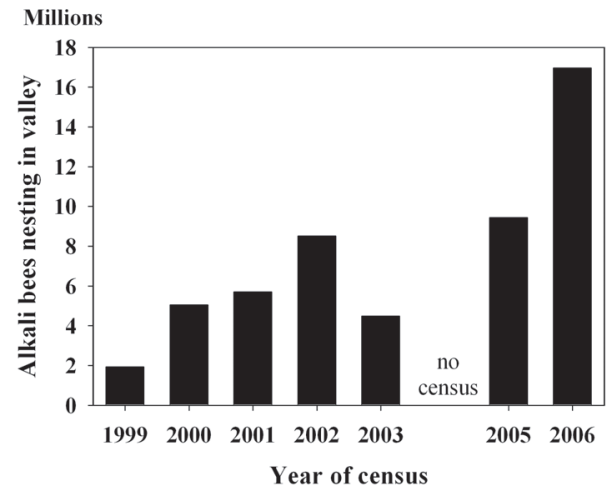

Figure 4. Sum of alkali bees nesting annually in the Touchet Valley of southeastern Washington.

multiplied through denser nesting on existing nest beds, adding an average of 8 nests per $\mathrm{m}^{2}$ annually $\left(r^{2}=0.77\right.$, slope $=8 \pm 2$ nests, $t=4.1, P \leq 0.01$ ) (Fig. 6).

\subsection{Subsurface moisture and aggregation growth}

Most nesting beds received supplemental subirrigation. One nesting bed with ample natural soil moisture (Maiden bed) was tripled in surface area by the grower to 3.8 ha over the 8-yr survey period; it ultimately became home to $9 \%$ of the valley's alkali bees (Fig. 7). Prior to surface salting and weed removal, nesting there was exceedingly sparse ( 0.2 nests per $\mathrm{m}^{2}$ ). Eight years later, the population had swelled to 39 nests per $\mathrm{m}^{2}$ (Fig. 3). Within nesting beds, the densest nesting accompanied moist but not wet soils (average tensiometer readings of $21 \pm 9 \mathrm{kPa}$ ), whereas sparsely populated areas of nesting beds were invariably drier (tensiometer readings $29 \pm 9 \mathrm{kPa}$ ) (Cane, unpublished data for 28 nesting beds) (Fronk and Painter, 1960). Adequate nest bed moisture is essential; growers who ceased subirrigating practices lost their Nomia populations on four large nesting beds.

\section{DISCUSSION}

Population sizes of alkali bees nesting in the Touchet Valley ultimately surpassed 


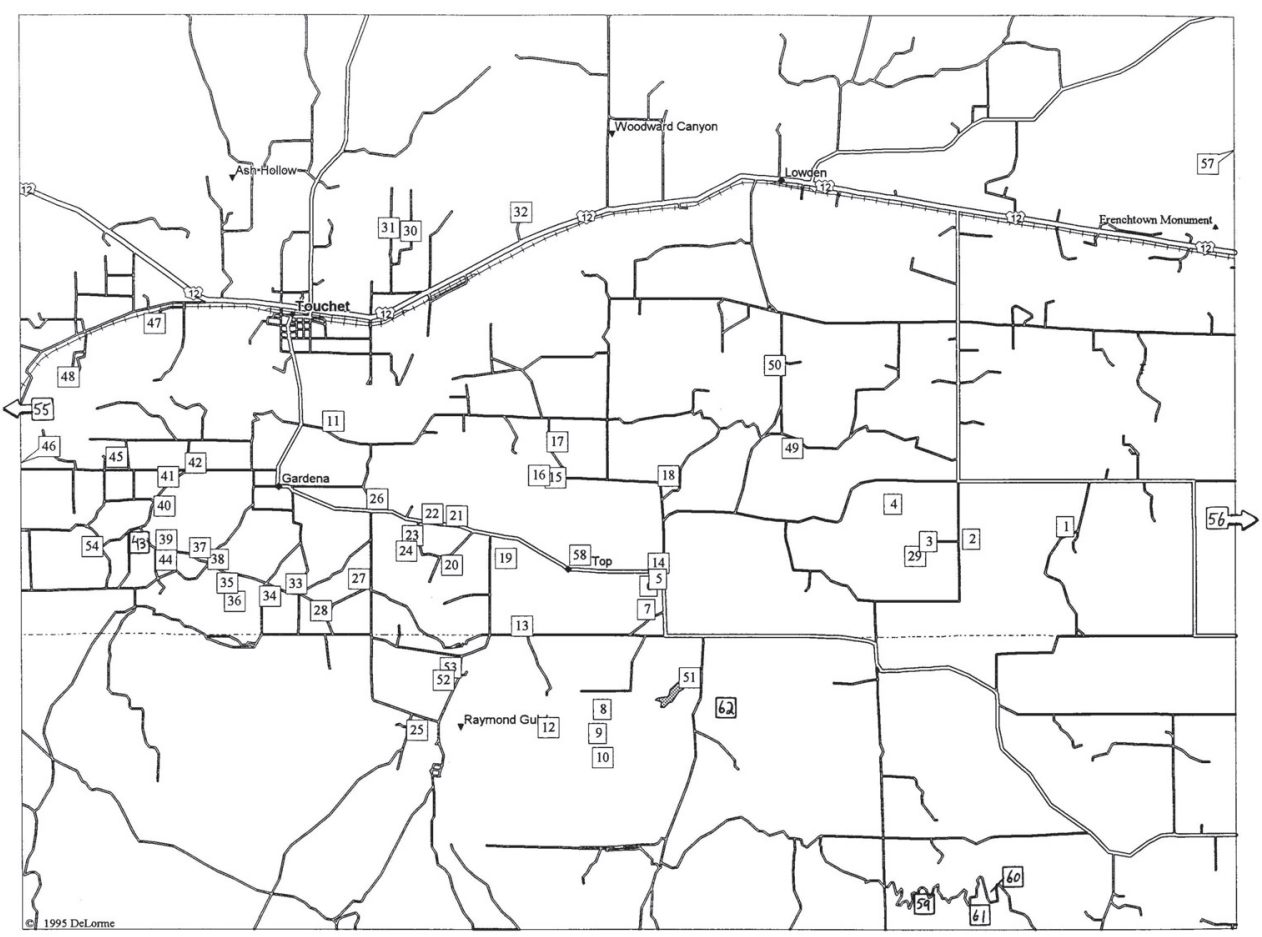

Figure 5. Map of numbered nesting beds surveyed during this study. Nest bed Nos. 46, 55, 56, and 57 are beyond the map boundaries. The image is $13 \mathrm{~km}$ wide.

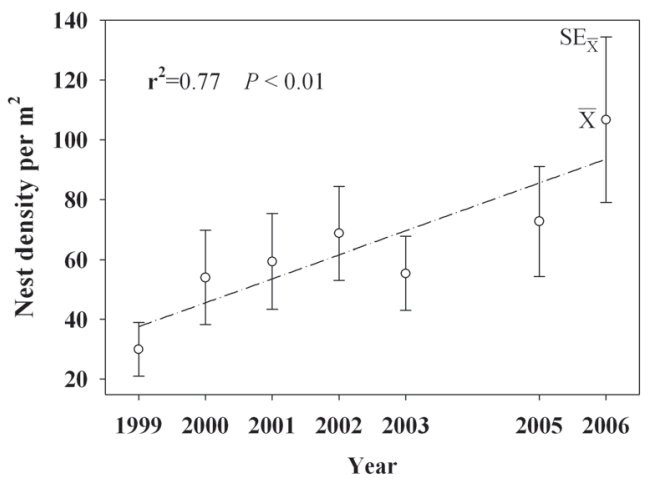

Figure 6. Valley-wide increase in average annual nesting densities of alkali bees in the Touchet Valley. Shown are the annual grand means and their standard errors, calculated from the mean densities for the 24 most populous surveyed beds. The linear regression is fitted to the eight annual grand means.

those reported for any other non-social bee in the world. This is true for both individual nesting aggregations (5.3 million at

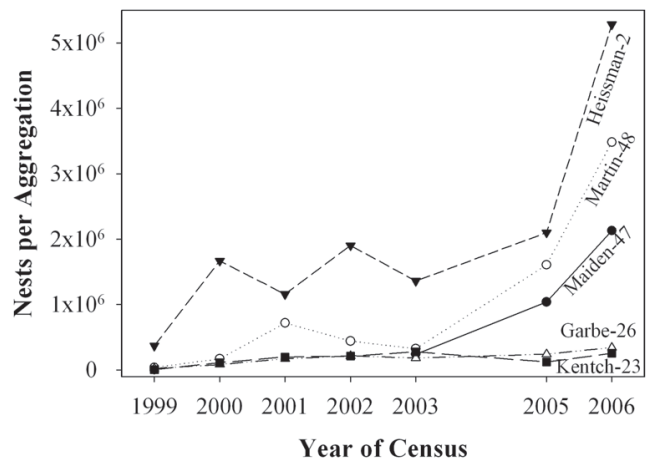

Figure 7. Population growth of five representative alkali bee nesting beds annually surveyed in the Touchet Valley. Names are those used by local growers; nest bed numbers from Figure 5 .

the Heismann Bed) and collectively for the 16.7 million alkali bees nesting in the valley. Previously, the largest bee metapopulation was found spread along $7 \mathrm{~km}$ of river bank in Russia, where Dasypoda plumipes 
and several co-nesting species were informally estimated to collectively comprise 12 million bees (Blagoveschenskaya, 1963). Estimates for populous individual aggregations of other ground-nesting bees include: 28000 nesting Andrena postomias (Maeta et al., 1988), 80000 nesting Mesoxaea texana (Cockerell, 1933), 155000 Dieunomia triangulifera (Minckley et al., 1994), 180000 Anthophora edwardsii (Al Washburn, unpubl. data) and 423000 Centris caesalpiniae (Rozen and Buchmann, 1990).

Longevities of some of these alkali bee nesting aggregations exceed all previous records for bees, verified by the following cases and evidence. A wild alkali bee nesting site near Preston Idaho noted by G.E. Bohart in 1971 remained populous 34 years later. In the Touchet Valley, several managed nest beds have been continuously populated for 50 years. For example, the artificially subirrigated "Sutherland" bed (Fig. 5 No. 23) was one of 104 sampled in 1958 as part of a nest soil survey (unpublished report by W.H. Weaver et al.). From 1973-1977, it was producing 80-186 alkali bee progeny per $\mathrm{ft}^{3}$ (Johansen et al., 1978). Thirty years later, from 2000 to 2006, its population was doubling to 250000 nests. Another managed nest bed (Fig. 5 No. 19) was built in the 1950's by the current grower's father; today it has 300000 nesting bees. Other now populous nesting sites (e.g., Maiden and Martin nest beds, Figs. 5 and 7) have existed for decades too, and were formerly populous. During the 1980's and early 1990's, they fell into disuse or were buried under sandy flood sediments. During the last eight years, site renovations fostered dramatic population recoveries (184-fold and 89-fold growth) (Fig. 7). The Heissman nesting bed was started in 1973 with eleven $1-\mathrm{ft}^{3}$ soil cores transplanted from natural aggregation No. 55 (Fig. 5). From reported prepupal densities that year (Johansen et al., 1978) the aggregation began with only about $550 \mathrm{fe}$ males. Thirty-three generations later, their descendants number 5.3 million nesting females, achievable through population doubling every two years, although actual growth is more sporadic (Fig. 7). The remarkable longevity and growth of nesting aggregations of the alkali bee is without published precedent, but such persistence may be more common than we know for bees that nest gregariously.

Most bee nesting aggregations are studied for a few years and are considered ephemeral. Scattered reports of long-lived nesting aggregations include: 20 years for Panurginus polytrichus (Neff, 2003), 22 years for Trachusa byssina (as T. serratulae) (Friese, 1923), 22-35 years for Dieunomia triangulifera (Minckley et al., 1994; Michener, unpubl. data) and 37 years for Lasioglossum malachurum (Stöckhert cited in Michener, 1974). Nesting sites of Trachusa perdita and T. gummifera were found still populous when revisited after 24-27 years (Thorp, unpubl. data). The paucity of such multidecadal records may reflect a failure to seek such data, rather than the rarity of the phenomenon. Nesting aggregations may decline with shifting habitat attributes that alter nesting suitability, such as shading from forest succession (Archer, 1989) or changing land use, rather than intrinsic brevity of gregarious nesting itself.

Why have managed alkali bees flourished in this valley when insecticides were implicated in demise of managed alkali bees introduced to California (Wichelns et al., 1992)? Several factors seem important. First, the primary crop in the Touchet Valley has been and continues to be seed alfalfa, an acceptable and timely floral resource for alkali bees. The valley produces an estimated one trillion alfalfa flowers annually, but periodic floral resource dearth can constrain population growth. The 2002-2003 decline in alkali bee populations (Fig. 4) followed shrinkage in acreage planted. The valley's rotational crops (wheat, field peas and chickpeas) do not feed bees, but neither are they sprayed with insecticides during alfalfa bloom. Hence, at midsummer and within an alkali bee's substantial flight range $\left(5-10 \mathrm{~km}^{2}\right.$ ) (Vansell and Todd, 1946), the valley's alkali bees are unlikely to contact any broad-spectrum insecticide. For alfalfa seed crops, Touchet growers conscientiously scout fields for pests such as Lygus bugs, aphids, and seed weevils, their spray decisions guided by economic damage thresholds. Growers typically anticipate and suppress threatening pest problems using one or more insecticides 
before or after bloom. The permitted pesticide repertoire includes eight herbicides and defoliants, and eleven insecticides (e.g. chlorpyrifos, dimethoate, naled) all applied from the ground to minimize drift. If pests threaten during bloom, only one broad-spectrum but short-lived insecticide (Dibrom) can be safely used (Johansen and Mayer, 1990). Otherwise, growers choose a narrow spectrum insecticide that is safe for bees. Nonetheless, in the early 1990s, some nesting populations in the western end of the valley crashed dramatically. Most growers implicate either use of a then new broad-spectrum insecticide, metasystox, applied during bloom, or a brief period of potato growing, a crop demanding frequent insecticide use. Metasystox, though safe for bees after $8 \mathrm{hrs}$ once dried on the foliage (Johansen et al., 1978), remains lethal on dewy foliage. Growers ceased using metasystox during bloom, and that was the last extensive dieoff of alkali bees in the valley. Paradoxically, extensive monocultures of seed alfalfa with little or no alternative bloom, coupled with conscientious use of conventional insecticides, has been compatible with fostering populations of this wide-ranging polylectic bee.

Among ground-nesting bees, the alkali bee's unusual suite of attributes may uniquely favor its intensive large-scale management. Alkali bees nest gregariously and densely, yet females can navigate unerringly to the entrances of their individual nests (Cane, unpubl. data). The single annual generation of managed alkali bees in Washington coincides with alfalfa bloom. Hence, the lack of alternative bloom during the remainder of the growing season is irrelevant, in contrast with the needs of social or multivoltine bees. The parasite/predator problems are amenable to control. The alkali bee's nesting habits allow artificial colonization of new sites. The silty damp nesting soils and shallow nests of alkali bees facilitate coring into soil blocks of manageable size (ca. $40 \mathrm{~kg}$ ), each containing hundreds of durable prepupae. Thousands of cores are used to initiate a newly prepared nesting bed. Many other ground-nesting bees known to be effective crop pollinators (Cane, 1997) nest more deeply, or in hard clays or friable sands that cannot be thus cut and moved.
The genus Nomia is unusual among bees for generally lacking specific cleptoparasitic bees (Michener, 2000). Only Nomada suavis Cresson attacks the alkali bee, albeit rarely if at all (Bohart, 1970; Johansen et al., 1978). Many ground-nesting bees commonly host specific cleptoparasites whose numbers can multiply and deplete their host's nesting aggregations (Thorp, 1969; Cane et al., 1996). The alkali bee's freedom from cleptoparasites is enigmatic. It may be partially explained by the Nomiinae having evolved no cleptoparasitic lineages, as cleptoparasites of many groups parasitize their relatives (Michener, 2000).

The alkali bee does host several significant larval parasitoids, however. An oil beetle (Meloe niger Kirby: Meloidae) infested 4-31\% of alkali bee nest cells in the Touchet Valley from 1973-1976, before control by pitfall trapping (Mayer and Johansen, 1978). Bee flies (Bombyliidae) can parasitize substantial numbers of ground-nesting bees, sometimes causing population declines (Packer, 1988; Bischoff, 2003). Larvae of the bee fly Heterostylum robustum (Osten Sacken) kill mature alkali bee larvae; early reports associated $90 \%$ parasitism by $H$. robustum with decimated large alkali bee nesting aggregations (Bohart et al., 1960). From 1965-1977 among Touchet Valley nesting aggregations, $H$. robustum parasitism accounted for $0-18 \%$ of sampled nest cell mortality (Johansen et al., 1978). Its impact on alkali bees has further diminished recently, a 6-state survey finding only $3 \%$ parasitism by $H$. robustum (R. Rust, unpublished data). The insignificance of these parasites in today's managed alkali bee nesting aggregations is puzzling, given that their fecundity far exceeds that of their hosts (Bohart et al., 1960; Mayer and Johansen, 1978; Alexander and Rozen, 1987).

Decades of intensive farming in the Touchet Valley (Fig. 1) have largely eliminated its native flora and bee communities (Cane, unpubl. data). The native alkali bee has persisted and proliferated, however, owing to active stewardship by alfalfa seed growers that both favors bee multiplication while minimizing natural and agricultural mortality factors. Growers foster bee reproduction by creating and maintaining large and suitable nesting sites, and 
adjust crop rotations to retain ample alfalfa bloom within the alkali bee's flight range. Growers protect population gains of their alkali bees from the potential of larval parasitoids and predators to multiply faster than their hosts. During alfalfa bloom, growers also conscientiously eschew insecticide applications of known bee risk. These practices, combined with serendipitous attributes of the alkali bee and the locale, have led to the most populous and long-lived individual nesting aggregations and landscape-scale metapopulations ever recorded for a native bee. Whether or not this success can be repeated with other valuable native pollinators remains to be seen.

\section{ACKNOWLEDGEMENTS}

Dan Mayer thoroughly introduced me to alfalfa seed farmers and the alkali bees they foster. Those farmers shared welcome cooperation, support and insights. Don Veirs, Faye Rutishauser, Melissa Weber, Katharine Swoboda and Stephanie Rowan-Miller assisted in this study. Robbin Thorp offered valuable unpublished observations. Vincent Tepedino and John Neff provided helpful reviews. I dedicate this study to the memory of Dr. George "Ned" Bohart.

Utilisation durable d'une abeille indigène qui nidifie dans le sol (Nomia melanderi) pour polliniser la luzerne dans un paysage d'agriculture intensive.

Halictidae / abeille solitaire / pollinisation / culture / luzerne / écologie du paysage / nidification grégaire / dynamique populations

\footnotetext{
Zusammenfassung - Nachhaltige Nutzung einer bodennistenden Biene (Nomia melanderi) als Bestäuber in einer landwirtschaftlich intensiv genutzten Region. Die Alkalibiene (Nomia melanderi) ist die weltweit einzige bodennistende Biene, die intensiv genutzt wird. Im Westen der USA wird sie seit über 50 Jahren als effizienter Bestäuber für Alfalfa (Medicago sativa L.) gehalten. In dem $240 \mathrm{~km}^{2}$ grossen Touchet Tal, einer AlfalfaAnbauregion im Staat Washington (Abb. 1), wurden die 24 populationsstärksten der 56 Nestaggregationen (Abb. 5) zwischen 1999 und 2006 in jährlichen Bestandsaufnahmen begutachtet (Abb. 6). Das Tal, das mit 2000-4000 ha an Alfalfa-Blütenfläche $1 / 4$ der gesamten US-Produktion darstellt, wies innerhalb dieser acht Jahre einen neunfachen An-
}

stieg in der Zahl an Alkalibienen auf (Abb. 4). Im Jahr 2006 wurden 17 Millionen Weibchen in dichten Nestaggregationen auf knapp 20 ha Talweite registriert (Abb. 2 und 3). Dies stellt damit die nachgewiesenermaßen grösste Metapopulation nichtsozialer Bienen dar, und mehrere Populationen sind seit über 50 Jahren und damit wesenlich länger registriert als andere Aggregationen von Bienennestern. Das am dichtesten besiedelte Nestbett mit 1,5 ha wuchs in dieser Zeit auf 5,3 Millionen nistender Weibchen an. Mit einer Dichte von über $1000 \mathrm{Nestern} / \mathrm{m}^{2}$ ist dies die grösste zahlenmässig erfasste Aggregation von Bienennestern. Die Pflegepraxis für die Haltung der Alkalibienen beinhaltet: angemessene Bewässerung der Nistflächen, Ausbringung von Salz auf der Bodenoberfläche und Unkrautentfernung, Bereitstellung einer adäquaten Alfalfablüte in Nestnähe, teilweise Parasitenkontrolle und bienensichere Praxis in der Ausbringung von Insektiziden. Lediglich eine nichtangemessene Bewässerung führte im Beobachtungszeitraum zu Verlusten inerhalb der Nistpopulationen. Diese umfassende regionalweite Bestandsaufnahme zeigte, dass eine gregäre einheimische Biene selbst in einem intensiv konventionell bewirtschafteten Landschaftsraum einen erheblichen Anstieg in den Individuenzahlen aufwies, und dass sich die Populationen für zumindest ein halbes Jahrhundert stabil hielten.

\section{Apiformes / Nutzpflanzen / Halictidae / Medica- go / Bestäuber}

\section{REFERENCES}

Alexander B., Rozen J.G. Jr. (1987) Ovaries, ovarioles, and oocytes in parasitic bees (Hymenoptera: Apoidea), Pan-Pacific Entomol. 63, 155-164.

Archer M.E. (1989) The wasps and bees (Hymenoptera, Aculeata) of Allerthorpe Common England UK before and after coniferization, Naturalist 114, 129-136.

Bischoff I. (2003) Population dynamics of the solitary digger bee Andrena vaga Panzer (Hymenoptera, Andrenidae) studied using mark-recapture and nest counts, Popul. Ecol. 45, 197-204.

Blagoveschenskaya N.N. (1963) Giant colony of the solitary bee Dasypoda plumipes Pz., Entomol. Obozr. 42, 115-117.

Bohart G.E. (1970) The evolution of parasitism among bees, in: Faculty Honor Lecture Utah State University, Logan, 41, 30 p.

Bohart G.E., Cross E.A. (1955) Time relationships in the nest construction and life cycle of the alkali bee, Ann. Entomol. Soc. Am. 48, 403-406.

Bohart G.E., Stephen W.P., Eppley R.K. (1960) The biology of Heterostylum robustum (Diptera: Bombyliidae), a parasite of the alkali bee, Ann. Entomol. Soc. Am. 53, 425-435. 
Bosch J. (1994) The nesting behaviour of the mason bee Osmia cornuta (Latr) with special reference to its pollinating potential (Hymenoptera, Megachilidae), Apidologie 25, 84-93.

Cane J.H. (1997) Ground-nesting bees: the neglected pollinator resource for agriculture, in: Richards K.W. (Ed.), Pollination: from theory to practice, Acta Hortic., Leiden, pp. 309-324.

Cane J.H. (2002) Pollinating bees (Hymenoptera: Apiformes) of U.S. alfalfa compared for rates of pod and seed set, J. Econ. Entomol. 95, 22-27.

Cane J.H. (2003a) Annual displacement of soil in nest tumuli of alkali bees (Nomia melanderi) (Hymenoptera: Apiformies: Halictidae) across an agricultural landscape, J. Kans. Entomol. Soc. 76, 172-176.

Cane J.H. (2003b) Exotic non-social bees (Hymenoptera: Apoidea) in North America: Ecological implications, in: Strickler K.V., Cane J.H. (Eds.), For non-native crops, whence pollinators of the future? Thomas Say Publications in Entomology, Entomological Society of America, Lanham, MD, pp. 113-126.

Cane J.H., Schiffhauer D., Kervin L.J. (1996) Pollination, foraging, and nesting ecology of the leaf-cutting bee Megachile (Delomegachile) addenda (Hymenoptera: Megachilidae) on cranberry beds, Ann. Entomol. Soc. Am. 89, 361-367.

Cockerell T.D.A. (1933) The excessive abundance of certain bees, Am. Nat. 67, 1-3.

Eck P. (1986) Cranberry, in: Monselise S.P. (Ed.), CRC Handbook of fruit set and development, CRC Press, Boca Raton, Florida USA, pp. 109-117.

Farrar C.L., Bain H.F. (1946) Honeybees as pollinators of the cranberry, Am. Bee J. 86, 503-504.

Free J.B. (1993) Insect pollination of crops, Academic Press, New York.

Friese H. (1923) Die europaischen Bienen (Apidae), Walter de Gruyter and Co., Berlin.

Fronk W.D., Painter L.I. (1960) Some characteristics of alkali bee nesting sites, J. Econ. Entomol. 53, 424-425.

Johansen C.A., Mayer D.F. (1990) Pollinator protection: A bee and pesticide handbook, Wicwas Press, Cheshire, Conn.

Johansen C.A., Mayer D.F., Eves J.D. (1978) Biology and management of the alkali bee, Nomia melanderi Cockerell (Hymenoptera: Halictidae), Melanderia 28, 25-46.

Klein A.M., Vassiere B.E., Cane J., Steffan-Dewenter I., Cunningham S., Kremen C., Tscharntke T. (2007) Importance of pollinators in changing landscapes for world crops, Proc. R. Soc. B 274 , 303-313.

Lesins K. (1950) Investigations into seed setting of lucerne at Ultuna, Sweden, 1945-1949, Ann. R. Agric. Coll. Sweden 17, 441-479.
Maeta Y., Sasaki Y., Fujimoto G. (1988) Andrena postomias of the Gakuonji temple in Hyogo prefecture, Insectarium 25, 50-57.

Mayer D.F., Johansen C.A. (1978) Bionomics of Meloe niger Kirby (Coleoptera: Meloidae) a predator of the alkali bee, Nomia melanderi Cockerell (Hymenoptera: Halictidae), Melanderia 28, 22.

Michener C.D. (1974) The social behavior of the bees: a comparative study, Harvard University of Press, Cambridge, Massachusetts.

Michener C.D. (2000) The bees of the world, Johns Hopkins Univ. Press., Baltimore.

Minckley R.L., Wcislo W.T., Yanega D., Buchmann S.L. (1994) Behavior and phenology of a specialist bee (Dieunomia) and sunflower (Helianthus) pollen availability, Ecology 75, 1406-1419.

Neff J.L. (2003) Nest and provisioning biology of the bee Panurginus polytrichus Cockerell (Hymenoptera: Andrenidae), with a description of a new Holcopasites species (Hymenoptera: Apidae), its probable nest parasite, J. Kans Entomol. Soc. 76, 203-216.

Packer L. (1988) The effect of Bombylius pulchellus (Diptera; Bombyliidae) and other mortality factors upon the biology of Halictus ligatus (Hymenoptera; Halictidae) in southern Ontario, Canada, Can. J. Zool. 66, 611-616.

Parker F.D., Batra S.W.T., Tepedino V.J. (1987) New pollinators for our crops, Agric. Zool. Rev. 2, 279-307.

Pedersen M.W., Nye W.P. (1962) Alfalfa seed production studies. Part II. Additional factors associated with seed yields, Utah Agric. Exp. Stn. Bull. 436, 9-22.

Pitts-Singer T.L. (2004) Examination of 'pollen balls' in nests of the alfalfa leafcutting bee, Megachile rotundata, J. Apic. Res. 43, 40-46.

Rozen J.G. Jr., Buchmann S.L. (1990) Nesting biology and immature stages of the bees Centris caesalpiniae, $C$. pallida and the cleptoparasite Ericrocis lata (Hymenoptera: Apoidea: Anthophoridae), Am. Mus. Novit. 2985, 30.

Stephen W.P. (1960) Artificial beds for the propagation of the alkali bee, Nomia melanderi, J. Econ. Entomol. 53, 1025-1030.

Thorp R.W. (1969) Ecology and behavior of Anthophora edwardsii (Hymenoptera: Anthophoridae), Am. Midl. Nat. 82, 321-337.

Vansell G.H., Todd F.E. (1946) Alfalfa tripping by insects, J. Am. Soc. Agron. 38, 470-488.

Wichelns D., Weaver T.F., Brooks P.M. (1992) Estimating the impact of alkali bees on the yield and acreage of alfalfa seed, J. Prod. Agric. 5, 512518.

Williams N.M., Minckley R.L., Silveira F.A. (2001) Variation in native bee faunas and its implications for detecting community changes, Conserv. Ecol. $5,57-86$. 